\title{
Application of musyarakah in Islamic banking
}

\author{
Sarpini ${ }^{1}$ \\ Institut Agama Islam Negeri Purwokerto, Indonesia
}

\begin{abstract}
Purpose - The purpose of this study is to explain syirkah, one of the popular profit-sharing scheme.

Method - This research is a descriptive analysis that describes all data and then analyzes the data to obtain a conclusion.

Result - This study concludes that the legal basis of syirkah is Al-Qur'an, Sunnah, ijma 'and its application in Islamic banking, namely project financing and venture capital.

Implication - Understanding one of the implementation of the profitsharing system mostly keeps the principle of justice running in the economy.

Originality-This study is essential to continue to be studied and explored considering there are still many issues of Islamic law (muamalah) that need to be resolved in sharia law.
\end{abstract}

Keywords: syirkah; mudharib; Islamic banking.

\footnotetext{
1 Author correspondence: Sarpini, sarpini@iainpurwokerto.ac.id, IAIN Purwokerto, Jl. A. Yani No.40A, Karanganjing,
} Purwanegara, Kec. Purwokerto Utara, Kabupaten Banyumas, Jawa Tengah 53126 
Sarpini

\section{Introduction}

In a country's economy, one financial institution that has strategic value is a bank financial institution. The institution is intended as an intermediary

JIEMB | 174 between parties who have excess funds with those who lack funds. Bank financial institutions are engaged in lending activities, and various services provided by banks serve financing needs and expedite payment system mechanisms for all economic factors.

Islamic Sharia, as sharia brought by the last apostle, has its uniqueness. This Sharia is not only comprehensive or comprehensive but also universal. This special character is needed because no other sharia will come to perfect it. Islamic Sharia summarizes all aspects of life, both ritual (worship) and social (muamalah) and can be applied at any time and place until the end of the day (Antonio, 2002).

The development of Islamic business is currently experiencing very rapid progress, especially those engaged in the financial sector, such as banking institutions, insurance, capital markets, mutual funds, and Baitul Mal wat Tamwil (BMT). In this connection, the concepts of muamalah fiqh also become important, because they serve as guidelines in the operations of these financial institutions. Among the concepts of muamalah that is quite important is syirkah.

The concept of syirkah is the main difference between Islamic financial institutions and conventional financial institutions. The concept of syirkah is an important instrument in Islamic monetary and finance and it is this concept that replaces the system of interest in financial institutions (Muhamad, 2018).

One of the most popular profit-sharing schemes in the world of contemporary economics is syirkah (Khan, 2008). This is what will be discussed in this study. This study is particular to continue to be studied and explored considering there are still many issues of Islamic law (muamalah) that need to be resolved in sharia law. 


\section{Literature Review}

\section{Consumptive behavior}

In capitalism, economics bank interest (interest rate) is a pulse in the contemporary economic system. There is almost no side to the economy, which escapes the credit interest rate mechanism (credit system). Starting from local transactions in all economic structures of the country to international trade.

Application of interest to the concept of the time value of money ensures profit in advance. Every business cannot be guaranteed to be successful in such a number, because in reality, every business must be faced with risks that contain the possibility of loss, profit, and return on capital. Profits can be big, medium and small. However, for centuries, the world economy has been dominated by the interest system, so that it has crystallized in every business activity of the world community.

The impact of such a massive development on the monetary sector impeded the development of the real sector. If it is assumed that the money supply is constant, then the credit system with the interest that is in the monetary markets will suck up the money supply. So it is not only monetary instability that is occurring, but also the decline in the real sector and the people's economy. Globally this slump will affect returns that are contested in the monetary sector. So if this continues to be the trend, then it is natural for some experts to predict a major economic crisis, not only in third world countries but also in developed countries (countries with capital).

Islamic Sharia firmly believes that pre-determined bank interest will exploit the economy, tends to occur misallocation of resources and the accumulation of wealth and power in a handful of people. This will lead to injustice, inefficiency, and economic instability.

In Islamic economics, the dichotomy of the monetary and real sector is unknown. The monetary sector in the definition of Islamic economics is a mechanism for financing transactions or production in the real market, so if 
Sarpini

using the conventional term, the characteristics of the Islamic economy are the real economy, especially trade. This is what Islam advocates, "Allah justifies the sale and purchase (trade) and forbids usury" (QS.2: 275). Buying or selling is a business activity in the real sector.

In shariah economy, a system of profit and loss sharing (Venardos, 2010), which then becomes the heart of the Islamic 'monetary' sector, not interest. Because in fact, the actual profit is sharing under the business climate that has a profit or loss prowess. Unlike the characteristics of interest that force the business results always to be positive. So the application of the profit-sharing system, in essence, keeps the principle of justice still running in the economy. Because indeed, economic stability comes from the principle of justice practiced in the economy.

\section{Research Methods}

The research method that will be used in this paper is descriptive qualitative research with library research approach, which will explain the pawn. The type of data used in writing this scientific paper is secondary data. Data sources in question are journals obtained from internet search results as well as books on sharia pawnshop management and also applicable regulations such as Laws (Laws), Government Regulations, and fatwas from DSN MUI. The use of secondary data in this study provides several advantages, especially related to the time and cost of research.

\section{Results and Discussion}

\section{Understanding}

Etymologically sharia means ikhtilath (mixing) (Suhendi, 2005) which is the mixing of one treasure with another so that it cannot be distinguished between the two. Furthermore, the word syirkah is used by Muslims for a partnership transaction in the business world (Az-Zuhaily, 1989).

In defining syirkah in terms of shar'i, the scholars have different emphases that result in different editorial formulations. Malikiyah said sharia is the granting of authority to the parties that cooperate. That is, each party gives 
authority to his partner over the assets owned together with still being authorized over their respective assets.

According to Hanabilah, the syirkah is the gathering of the rights and authority to convert the syirkah business. According to Shafi' iyah, syirkah is the existence of rights in a business owned by two or more people. According to Hanafiyah, the syirkah is a contract that occurs between two people who are bound in capital and profit.

A more precise and clear definition is Hanafiyah's definition because he explicitly explains the nature of syirkah as a contract of business cooperation between two parties in which each party contributes capital, and profits are shared according to the agreement (Sugihanto, 2011). Other definitions do not refer to the substance of syirkah but rather to the implications of syirkah itself. This can be seen from the keywords they use in defining syirkah, namely the word rights (istihqaq) and authority (tasharruf).

\section{Sharia foundation}

The basic syari'ah concept of syirkah is found in the Qur'an, Sunnah and ljma'.

1) Al Qur'an

"...... verily most of the people who associate some of them do wrong to others, except those who believe and do good deeds; and very few of them ... " (QS. Shad (38):24)

The word Al-Khulatha 'in the above verse means people who are in association (syuraka').

2) Al-Hadith

A hadith qudsi (Susamto, 2008) narrated by Abu Hurairah - marfu '-, that prophet Muhammad said:

"Verily Allah' Azza wa Jalla said, I am the third party of two people who are in an association as long as one of them does not betray the other (H.R.Abu Daud and Hakim and they confirmed this hadith). 
Sarpini

The purpose of this hadith is that Allah will look after and help those who are grateful by giving additional wealth and giving blessings to their trade. If anyone betrays, then the blessing and assistance are revoked by Allah.

The Messenger of Allah also said, "The hand of God rests on two people who are united while not betraying" (Mentioned by Ibn Qudamah in AlMughni: 5/1).

3) ljma'

The scholars have consensus (ijma ') to allow shirkah despite differences of opinion in matters of detail.

\section{Types of syirkah}

There are two types of syirkah (Yasin, 2009):

1. Syirkah Amlak; that is, two or more people own property/assets, which are not caused by the Syirkah contract. This ownership partnership is created because of inheritance, wills, joint purchase, joint ownership, or other conditions that result in ownership of one asset by two or more people. Syirkah Amlak is divided into two types, namely syirkah ikhtiyar and syirkah jabar.

a. Syirkah ikhtiyar, that is syirkah that occurs by the actions of two people who work together, such as when both of them buy, are given or inherited then both of them accept, so that something becomes a common property for both.

b. Syirkah jabar; syirkah that occurs not by the actions of two or more parties as syirkah ikhtiyar above, but they have it automatically, forced and cannot evade (jabari), like two people who inherit something, so both people have the same the right to the inheritance.

2. Syirkah 'Ukud; a transaction carried out by two or more people to associate in capital and profit. In the syariah, there is no jabari character. Therefore, all syirkah ukud are ikhtiari, so that legislation (positive in Egypt) calls it syariah ikhtiyariyah. The scholars differed in dividing the types of syirkah 'ukud. According to Hanabilah, syirkah 'ukud there are 5 types, namely: 
syirkah 'inan, syirkah mufwadhah, syirkah abdan, wirk syirkah, and syirkah mudharabah. According to Hanafiyah, there are three types of syirkah, namely: syrikah amwal, syirkah a'mal, and wirk syirkah.

Each syirkah consists of two types of syirkah, namely syirkah mufawadhah and syirkah 'inan. So in total, there are six types of syirkah. Meanwhile, JIEMB | 179 according to Malikiyah and Shafi'iyah syirkah there are four types: syirkah inan, syirkah mufwadhah, syirkah abdan, and syirkah wujuh.

The scholars agree that syirkah 'inan is permissible, while for other types of syirkah, there are differences of opinion among the scholars. Shafi'iyah only allows syirkah 'inan and syirkah mudharabah. Hanabilah allows all types of syirkah except syirkah mufawadhah. Malikiyah allows all shirkahs, except the seven wikhs and mufawadhah. Hanafiyah and Zaidiyah allow all types of syirkah if they meet the specified requirements.

Although there are quite many types of syirkah, this paper only discusses five types of syirkah, namely Inan, mufawadhah, abdan, wujuh and mudharabah. This is because the study of syirkah is very broad.

3. Syirkah Inan; is a contract between two or more people. Each party provides a portion of the total funds and participates in the work. The two parties share the gains and losses as agreed between them. But the portion of each party, both in funds, work results and profit sharing is different, according to their agreement.

4. Syirkah Mufawadhah (Nawawi, 2011); Are two or more people conducting business unions with the condition that there are similarities in capital, profit and loss sharing, work equality, responsibility and debt burden. One party is not allowed to own more shares (capital) than its partners. If one party has a capital stock of 1000 dinars, while the other party has 500 dinars, then this is not the mufawadhah syirkah, but it becomes the syirkah inan. Likewise, other aspects must have in common.

5. Syirkah abdan/charity (An Nabhani, 2010); is a contract of cooperation of two or more people to accept work together and share the benefits of the job, such as tailors, blacksmiths, carpenters, arsirtek, etc. For example, two 
Sarpini

parties agree and say, "We unite to work and the benefits are for both of us". This syirkah is often also called syirkah abdan or shana'iy.

6. Syirkah Wujuh; Is a business contract between two or more people who have a good reputation and prestige, where they are trusted to develop a business without capital. For example, they are trusted to carry merchandise without cash payments. This means that they are trusted to buy the goods on credit and then trade the goods for profit. They share in the profits and losses based on the supplyer's guarantee to each of them. Because this business does not require capital, this contract is commonly referred to as a credit receivable cycle.

\section{Pillars and syirkah terms}

According to jumhur 'ulama, there are three kinds of syirkah:

1. Contracting party

Required that partners must be competent (legally competent) in the transaction and of course competent in giving or receiving representative power.

2. Agreement object (ma'qud 'alaih)

The object of strength in this syirkah are two elements, namely funds (capital) and work. The funds (capital) provided must be cash. But some other scholars provide the possibility if tangible capital in trading assets, such as goods, property, etc. It can even be in the form of non-physical rights, such as licenses and patents. If that is done, all capital must be assessed in advance in cash and agreed upon by its partners.

Participation and intervention of partners in the musyarakah business are fundamental. It is not justified if one party states that they did not participate in handling the work in the syirkah. Even if he does not want to be directly involved, he must represent it to his partner. So, the type of business undertaken in this syirkah must be able to be represented to others. This is important, because in reality, often a partner represents the company to enter into a transaction agreement with another company. 
One party may handle more work than the other and has the right to demand more profit sharing from him in accordance with the agreement. Then, the parties may not borrow, lend, donate or gift musyarakah capital to other parties, except on the basis of an agreement.

\section{Speech}

There is no special form of syirkah contract. The editor of the contract can be in the form of a verbal (verbal) or written statement that shows the agreement and agreement to conduct a business partnership. This syirkah contract must be documented.

\section{Laws relating to syirkah}

1) Profit law (Rivai, 2010)

a. The profits derived from operating results must be clearly known in quantitative quantities. This is intended to reinforce the basis for contracting the syirkah so as not to lead to disputes at the time of the allocation of profits or termination of the syirkah contract. Each partner must know the number of shares and the proportion (ratio) of profit, for example $20 \%, 50 \%$ and so on.

b. Distribution of profits must be proportional according to the amount of capital of each party. Thus, a partner who deposited a capital of 1000 dinars, had a different share of profits with a partner who deposited 500 dinars. Then the profit sharing must be based on the ratio.

c. A partner is not allowed to determine his own share of profits at the beginning of the contract, because it reduces the basis and philosophy of shirkah and violates the principle of justice.

d. But according to the Hanafi and Hanbali schools, profit sharing does not have to be proportional to capital as stated above. This is when the partners make certain conditions in the contract. Their argument is based on the view that profits are not only the result of capital, but the result of capital and labor. If one partner is more experienced or has the skills of another partner, it is permissible for him to require an additional portion 
Sarpini

of his profit as compensation for his skills and more work. Both schools of thought give an argument by quoting the phrase Ali ibn Abi Talib, "Profits must be in accordance with what they specify, while losses must be proportional to their capital".

2) Law on Loses

The scholars agree that losses must be shared among the partners in proportion to their respective shares in capital. This opinion is based on the words of Ali ibn Abi Talib above. In the case of continuous or long-term musyarakah, it is permissible to postpone the allocation of losses so that they can be compensated with profits in subsequent periods.

\section{Laws relating to the termination of musyarakah}

In principle, musyarakah will cease if one of the partners terminates the contract or dies of legal competence to cease (such as crazy) or the musyarakah capital lost / lost. Musyarakah is based on representation and integrity (Ulum, 2011). Each partner is a representative for the other. Representation is a contract that has been agreed upon by all scholars.

No party can be forced to continue a partnership that is against their will, so each partner has the right to stop the shirkah whenever he wants, as long as in accordance with the initial agreement. However, in the case of a deceased person, one of his heirs who is baligh and sensible can replace the position of the deceased partner. This of course requires the approval of other heirs and their musyarakah partners. These provisions should be made in the articles of the Shirkah agreement. Syirkah also ends if capital is lost or damaged.

\section{Legal foundation of musyarakah financing in Islamic banking practices}

Indonesian Banking Law, namely Law No. 7 of 1992 concerning Banking as amended by Act No. 10 of 1998, has given recognition of the existence of sharia principles in the Indonesian banking world by differentiating banks based on their business activities into two, namely banks that carry out conventional business activities and banks that carry out business activities based on sharia principles. 
As stated in Article 1 paragraph (13) of the Banking Act provides limits on the understanding of sharia principles as a rule of agreement under Islamic law between the Bank and other parties for depositing funds and / or financing business activities, or other activities that are declared in accordance with sharia, among others, financing based on the profit sharing principle (mudharabah), financing based on the principle of equity participation (musyarakahh), the principle of buying and selling goods for profit (murabahah), or financing of capital goods based on the principle of pure lease without choice (ijarah), or with the choice of ownership transfer for goods rented from the Bank by another party (ijarah wa iqtina).

Specifically in 2008, Law Number 21 Year 2008 concerning Sharia Banking was specifically regulated, including Article 1 number 25 which states that Financing is the provision of funds or claims equivalent in the form of profitsharing transactions in the form of mudharabah and musyarakah (Law - Law Number 21 Year 2008).

Financing based on the musyarakah agreement as one of the fund distribution products also has a legal basis in PBI No. 9/19 / PBI / 2007 concerning the Implementation of Sharia Principles in Funds Collecting Activities and Sharia Bank Services, as amended by PBI No. 10/16 / PBI / 2008.

Musyarakah is also regulated in the DSN Fatwa regulation No. 08 / DSN MUI / IV / 2000 (Wirdyaningsih, 2005) dated April 13, 2000. The essence of the DSN Fatwa states that community needs to improve welfare and business sometimes require funds from other parties, including through musyarakah financing, namely financing based on a contract of cooperation between two or more parties for a particular business in which each party contributes funds provided that the benefits and risks will be borne together in accordance with the agreement (Anshori, 2009).

\section{Application of musyarakah in Islamic banking}

Syirkah which is divided into several types above in Islamic banking the term used is musyarakah. Musyarakah agreements between banks and 
Sarpini

customers are mostly carried out by entrepreneurs, where entrepreneurs want to develop their business.

Profit sharing is the distribution of the results of operations that have been JIEMB | 184 carried out by the parties entering into an agreement, namely the customer and the Islamic bank. Two parties that enter into the business agreement, the results of the business carried out by both parties or one of the parties, will be divided according to the portion of each party that entered into the agreement. The distribution of results of operations in sharia banking is determined by using the ratio. Ratio is the percentage agreed by the two parties in determining the profit sharing for the cooperated business (Ismail, 2011).

Islam uses the principle of profit sharing, because it is seen from several principles contained in Islamic sharia, as follows:

The pattern of cooperation gives enthusiasm to try productively

1. Improve welfare and prevent economic disparity

2. Preventing economic oppression and unequal distribution of wealth, or based on the principle of justice

3. Protect weak economic interests

4. Help institutions based on cooperation, so that the "strong helps the weak" relationship prevail

5. The existence of a work ratio and illustrates mutual help and interdependence.

Determination of the applicable profit sharing can be determined by the following steps:

1. Determination of the ratio of profit sharing is made at the time of the contract based on the possibility of profit and loss.

2. The amount of profit sharing ratio is based on the number of profits obtained.

The factors that influence the profit sharing are as follows (Ismail, 2011): 
1. Investment rate

Investment rate is the percentage of funds reinvested by Islamic banks both in financing and channeling other funds. For example, the statutory reserve is $8 \%$, so the total funds that can be invested by Islamic banks is $92 \%$. This will affect the revenue sharing received by investor customers.

2. Total investment fund

The total investment funds received by Islamic banks will affect the profit sharing received by investor customers. The total funds derived from mudharabah investments can be calculated using a minimum monthly balance or daily balance. Investment rate multiplied by the amount of funds available to invest will produce the actual amount of funds used (Muhammad, 2018).

3. Fund types; mudharabah investments in raising funds can be offered in several types namely; mudharabah savings deposits, mudharabah deposits, and syariah interbank mudharabah investment certificates (SIMA).

4. Ratio; ratio is a certain percentage mentioned in the business cooperation agreement (mudharabah and musyarakah) that has been agreed between the bank and the investor customer.

5. Profit Sharing Calculation Method; profit sharing will be different depending on the basis for the calculation of revenue sharing, namely revenue sharing calculated using the concept of revenue sharing and revenue sharing using profit / loss sharing.

Funds that have been collected by Islamic banks from third party funds over other deposits, need to be managed with trust and istiqomah. The main principles that must be developed by Islamic Banks in relation to fund management are that: Islamic Banks must be able to provide profit sharing to depositors of at least equal to or greater than the interest rates applicable in Conventional Banks, and 
be able to attract profit sharing from lower debtors than the interest prevailing in Conventional Banks.

Therefore, Islamic Bank fund management efforts need to be done well. The good management of funds carried out by Islamic Banks will show credibility in front of public trust to save funds. So that the direction to achieve: liquidity, profitability, and solvency of Islamic banks can be achieved.

6. Accounting policy

Some accounting policies that will affect profit sharing include depreciation. Depreciation will affect the bank's operating income. If the profit sharing uses the profit / loss sharing method, then depreciation will affect the profit sharing, but if you use revenue sharing, the shrinkage does not affect the profit sharing.

Then regarding the profit sharing ratio is the percentage of profits to be obtained shahibul mall and mudarib which is determined based on the agreement between the two. If the business loses due to business risk, not due to negligence of mudarib, then the distribution of losses is based on the portion of capital paid by each party. Because all capital invested in mudharib business belongs to Shahibul mal, then losses from the business are fully borne by Shahibul Mal. Therefore, the profit sharing ratio is also called the profit ratio. (Muhammad, 2004).

The profit sharing ratio consists of:

1. Percentage

Profit sharing ratio must be stated as a percentage (\%), not in a nominal nominal amount (Rp).

2. Profit and Share

The distribution of profits is based on the agreed ratio, while the distribution of losses is based on the portion of capital of each party.

3. Guarantee 
The collateral that will be requested is related to the character risk that mudharib has because if the loss is caused by the bad character of the mudharib, then the mudharib is the one who bear it. However, if losses are caused by business risk, Shahibul Mall is not allowed to ask for collateral from Mudharib.

\section{Magnitude of Ratio}

The profit sharing ratio figures appear as a result of bargaining based on agreement from the shahibulmal and mudarib.

5. How to Resolve Losses

Losses will be borne from the profits in advance because profits are the protectors of capital. If the loss exceeds the profit, it will be taken from the principal.

According to Syafi'i Antonio in his book entitled Sharia Bank Discourse Ulama And Scholars explained that the practice of musyarakahh in Islamic banking is widely applied in two ways, namely in project financing and also venture capital.

1. Project financing

Musyarakahh is usually applied for project financing where customers and banks alike provide funds to finance the project. After the project is completed, the customer returns the funds together with the agreed profit sharing.

2. Venture capital

Banks are allowed to invest in company ownership. Investments are carried out for a certain period of time, and after that the banks divest, both briefly and gradually (Antonio, 2002).

After the project is completed, the customer returns the funds together with the agreed profit sharing for the bank (Antonio, 2001). The benefits that arise from Musyarakah financing include:

1. Financial institutions will enjoy an increase in a certain amount when the customer's business profits increase, 
Sarpini

2. The principal repayment is adjusted to the customer's cash flow or cash flow, so that it does not burden the customer,

3. Financial institutions will be more selective and prudent.

So the purpose and benefits of musyarakahh financing in Islamic financial institutions can be beneficial in principle for both parties, namely from the institution (bank) and the customer (investor), the most important of which is having to trust each other and be responsible, and be trusted in carrying out business partnerships itself.

\section{Conclusion}

From the explanation that has been presented in advance, it can be concluded that the syirkah is a contract of business cooperation between two parties in which each party contributes capital, and profits are divided according to the agreement. The basic syari'ah concept of syirkah is found in the Qur'an, Sunnah and ljma '. There are two kinds of syirkah namely Amlak Syirkah and 'Ukud Syirkah.

The application of syirkah in Islamic banking is project financing and venture capital. The legal basis for musyarakah financing in sharia banking practices is Law Number 21 of 2008 concerning Sharia Banking. PBI No. 9/19 / PBI / 2007 concerning the Implementation of Sharia Principles in Funds Collecting Activities and Sharia Bank Services, as amended by PBI No. 10/16 / $\mathrm{PBI} /$ 2008. Musyarakah is also regulated in the DSN Fatwa regulation No. 08 / DSN MUI / IV / 2000.

The purpose and benefits of musyarakahh financing in Islamic financial institutions can be beneficial for both parties, namely from the institution (bank) and the customer (investor), the most important of which is having to trust each other and be responsible, and be trusted in carrying out the business partnership alone. 
Application of musyarakah in Islamic Bankings....

\section{References}

Al-Muslih, Abdullah. Fikih Ekonomi Keuangan Islam terj. Abu Umar Basyir. Jakarta: Darul Haq.

Al-Sajistaniy, Abu Daud Sulaiman Al-Asy-'ats. Sunan Abu Daud, Juz III. Beirut, Darul Fikri.

An Nabhani, Taqiyuddin. Sistem Ekonomi Islam. Bogor: Al Azhar Press, 2010.

Anshori, Abdul Ghofur. Perbankan Syariah di Indonesia. Yogyakarta: Gadjah Mada University Press, 2009.

Antonio, Muhammad Syafi'i. Bank Syariah, Dari Teori Ke Praktek .Jakarta: Gema Insani Press, 2002.

Az-Zuhaily, Wahbah. Al-Figh al-Islami wa Adillatuhu, Juz IV. Darul Fikri: Beirut, 1989.

Burhanuddin S, Hukum Perbankan Syariah di Indonesia. Yogyakarta: UII Press, 2008.

Dewi, Gemala. Aspek-Aspek Dalam Perbankan dan Perasuransian Syariah di Indonesia. Jakarta: Kencana, 2006.

Khan, M. Mansoor, et. all, Developments in Islamic Banking. England: Palgrave Macmillan, 2008.

Muhamad, Manajemen Dana Bank Syari'ah. Depok: PT RajaGrafindo Persada, 2017.

Muhamad, Teknik Perhitungan Bagi Hasil dan Pricing di Bank Syariah. Yogyakarta: UII Press. 2004.

Nawawi, Ismail Perbankan Syariah. Surabaya: Vivpress, 2011.

Purnamasari, Irma Devita et all. Panduan Lengkap Hukum Praktis Populer, Kiat-kiat Cerdas, Mudah, Dan Bijak Memahami Bank Syariah. Bandung: Kaifa, 2011.

Rivai, Veithzal. Islamic Financial Management. Bogor: Ghalia Indonesia, 2010.

Sjahdeini, Sutan Remi. Perbankan Islam dan Kedudukannyadalam Tata Hukum Perbankan Indonessia. Jakarta: Pustaka Utama Grafiti, 2007.

Sugihanto. Peluang Bank Syariah Dalam Pemberdayaan Ekonomi Umat .Ponorogo: STAIN Ponorogo Press, 2011. 
Sarpini

Suhendi, Hendi. Fiqh Muamalah. Jakarta: PT. Raja Grafindo Persada, 2005.

Ulum, Fahrul. Perbankan Syariah di Indonesia. Surabaya: Putra Media Nusantara, 2011.

Venardos, Angelo M. Current issues in Islamic banking and finance: resilience and stability in the present system. Singapore: World Scientific Publishing, 2010.

Wirdyaningsih, et, all. Bank Dan Asuransi Islam di Indonesia. Jakarta: Kencana, 2005.

Yasin, M. Nur. Hukum Ekonomi Islam, Geliat Perbankan Syariah di Indonesia. Malang: UIN Malang Press, 2009.

Muhamad, Manajemen Bank Syariah Yogyakarta: UPP STIM YKPPN, 2018. 